\title{
Mobile augmented reality adapted to the ARCS model of motivation: a case study during the COVID-19 pandemic
}

\author{
Luis Laurens-Arredondo ${ }^{1}$
}

Received: 29 July 2021 / Accepted: 1 February 2022 / Published online: 26 February 2022

(c) The Author(s), under exclusive licence to Springer Science+Business Media, LLC, part of Springer Nature 2022

\begin{abstract}
The rushed introduction of online education for universities because of the current covid-19 health crisis, has started to affect the quality of education for millions of students around the world. This pandemic has emphasized the need to improve the teaching process through the use of innovating educational tools, such as mobile augmented reality (mAR). This pilot study intends to evaluate the relationship between motivation and meaningful learning for university students through mAR, as well as the effects and implications of its use how supporting teaching activities in an Industrial Design and Technical Drawing course. A quantitative method research approach was applied to collect, process, and analyze the research data of the students' perception under the health restrictions caused by the current pandemic, using the Instructional Materials Motivation Survey (IMMS). The total number of questionnaires collected was 96, applied to students of the Industrial Engineering major at Universidad Católica del Maule in Chile. The instrument's reliability was measured using Cronbach's alpha, giving an overall value of 0.89 . The implementation of an instructional model called ARCS (Attention-Relevance-Confidence-Satisfaction) was achieved. The implementation of mRA was positively valued by most of the students surveyed. An increase the percentage of students who achieved the expected learning objectives was found, in compared to previous versions of the course (without mAR). Finally, the results demonstrate a positive relation between $\mathrm{mAR}$ and the learning level achieved by students. There was no evidence of negative effects under the particular imposed conditions, because of sanitary restrictions when implementing the mAR.
\end{abstract}

Keywords Mobile augmented reality $\cdot$ ARCS $\cdot$ Motivation $\cdot$ Pandemic

Luis Laurens-Arredondo

llaurens@ucm.cl

1 Departamento de Computación e Industrias, Universidad Católica del Maule, Talca, Chile 


\section{Introduction}

The current COVID-19 pandemic has negatively affected the education of almost $90 \%$ of the world's student population (Monasterio \& Briceño, 2020), mainly because most institutions decided to avoid in-person classes, in order to prevent the spread of the virus in the different educational contexts. This pandemic has forced a rushed adaptation and migration of the teaching process to an online context, which added to the few digital skills both teachers and students possess (Fardoun et al., 2020), the weak technological infrastructure in institutions, and the lack of processes to support virtual education (Mad et al., 2020), has made teaching more complex, and it has made to use of ICTs and improvisation the main characteristics of the current teaching-learning process (Ríos, 2020).

Distance learning, during the pandemic, has been addressed by various researchers (Blizak et al., 2020; Fauzi \& Khusuma, 2020; Mojibur, 2020; Nugroho et al., 2020), reaching a consensus on the negative perception, of students when using this new digital education, classifying it as inefficient (Bahasoan et al., 2020), given the frequent problems with accessibility and connectivity (Nur et al., 2020), as well as the excessive load of work that is generated by its implementation (Alchamdani et al., 2020), even though they recognized the huge support given by the teaching staff during the pandemic (Aristovnik et al., 2020). All the above creates the need for new tools and adjust the current methodologies so that they better mold to the particular circumstances lived by society nowadays, aiming to achieve an effective learning (Lecon, 2020). In this sense, using innovative strategies to motive students to learn in unconventional educational environments seems to be the solution, that is where mobile learning (m-learning) comes into picture, proving to be one of the most accepted strategies among university students, which is why it is recommended by various researchers (Hidayah, 2020), to improve the teaching-learning process in this health crisis that envelops humanity. Among these innovative strategies, Mobile Augmented Reality (mAR) has proved to be one of the most efficient ones to ease the learning experience and promote motivation in the current university context (Copertari \& Lopes, 2020).

\subsection{The relationship between learning, technologies, and motivation}

mAR is defined as technology that uses smart mobile devices to facilitate the combination between real life elements and virtual elements (Laurens-Arredondo, 2020). This particular articulation is not only remarkable and appealing for students but also allow for the development of interesting activities with students that make cross-disciplinary learning beyond the classroom's wall. In other words, everywhere, which makes its im-plementation under the current educational conditions ideal. The lessons drawn from applying this type of technology in a university context reflect that the best practices answer to an educational focus from a constructivist legacy, oriented towards active learning, for students are the ones who direct how the augmented information should be combined (Oliva et al., 2019), therefore, the relation to the learning objective is not only based on consulting the intellectual content but it also implies an immersive experience in the learning environment (Banchoff et al., 2019). 
These types of educational tools has the potential to improve student's motivation for learning, in an almost instant way (García, 2020), being their positive effects proportional to this generated motivation, which implies significant learning in a teaching model based on innovation (Alioon \& Delialioğlu, 2019).

Motivation, on the other hand, can be understood as a determining reason for people's actions or conducts (Cabero et al., 2017). This psychological construct is frequently used to reference the way a student processes their learning, as well as a dimension linked to the quality of the learning process, meaning, learning contents and skills that develop in university classes (Cruz et al., 2009). The relationship between motivation and learning has been described by Gagné et al.'s (1987) theory of learning as an element that facilitates storage and retrieval of information, classifying it as the engine of learning, which makes it essential for the modern educational process (Carrillo et al., 2009; Noguera et al., 2012), This relationship has been studies by various researchers by implementing different methodologies, from the most conservative ones (Cañabate et al., 2014) to the most disruptive ones (Gómez-Carrasco et al., 2019), having their findings of the positive influence of motivation on learning in students as a common ground.

Various researchers have addressed using and choosing mAR as an innovative element in education during the pandemic, like the one done by Chin \& Wang (2021), who suggested an authentic learning activity based on an augmented reality that allowed students to observe and learn key information about cultural heritage sites in a Taiwanese university. Faridi et al., (2020), who developed methodology for learning environment based on helping students understand concepts related to magnetic fields and electrical currents, proving that this experience helped students understand abstract physics concepts. Iwanaga et al. (Iwanaga et al., 2020) analyzed evaluation methods where the advantages of AR to solve access difficulties of medicine students to corpses. Martínez \& Cevallos (2021) used AR tools for students to study, analyze, and understand the COVID-19 virus. Müssig et al., (2020) approached the combination of hands-on work with the use of AR for house laboratory experiments to teach the science of materials, obtaining a positive response from students. Ratten (2020), suggested the use of AR to simulate the real educational environment of teaching entrepreneurship in university, which enabled students to have a bigger approach to community and to the corporate spirit. Sepasgozar (2020) addresses the implementation of AR in civil construction classes in distance learning during COVID-19. All of them agree on the positive impact of implementing AR technology in the teachinglearning process, and the show evidence of its potential to increase students' interest to learn.

\subsection{Design theory of ARCS motivational learning}

The ARCS training model was developed by Keller (1987a). His theoretical basis is founded on the theory of expected value. The ARCS model was developed as a response of wanting to find more effective ways of understanding the main influences of motivation in the learning process. Given that the ARCS model is a teaching model based on the student, it requires intensive student to student and student to teacher communication, which is the basis of effective learning (Aş1ksoy \& Özdaml, 
2016). Implementing the ARCS model while using information and communication technologies (ICT), consists of 4 basic dimensions: attention, relevance, confidence, and satisfaction (Chang et al., 2019; Loorbach et al., 2015). These are described as follows:

- Attention (A): Using ICTs in new contexts has as an objective to catch student's curiosity, enthusiasm, and interest at first instance, leading to an active participation. Inte-grating ICT must be unexpected and new in the classroom.

- Relevance (R): Refers to the student's feelings of connection between the innovative element introduced in the learning process and their own experiences, needs, and preferences.

- Confidence (C): This is related to the student's personal feeling of sensation and expectation of success; the thought that the student will finalize the learning process when the instruction reaches its end.

- Satisfaction (S): This dimension is related to the positivity with which the student confronts learning experiences. Therefore, if they are satisfied with the experience because they are proficiently completing tasks, then they sustain suitable motivation levels.

Despite implementing the ARCS model in different countries and contexts, the results from the studies are not consistent. This is because some learning strategies might not work on certain student population or a particular learning environment (Li \& Keller, 2018). Taking this into account and considering UCM's School of Engineering Sciences (also FCI) need for innovation in this field, this study aims to be a pilot study to measure how university students' motivation is impacted under particular conditions.

Finally, this study seeks to answer the following research questions (RQ):

- RQ1: Can you apply mAR technologies to the ARCS model of motivation?

- RQ2: Is it possible to apply a waterfall model for the design of an mRA project in times of pandemic?, What would be its main issues?

- RQ3: Is there a positive relationship between mAR implementation and learning?

- RQ4: Which is the right method to quantify the motivation of university students when using innovative technologies?

To answer these RQ we developed a methodology focused on motivation. We used a technological tool, that is supported by smartphones, which used the mAR in industrial design and technical drawing classes. We followed the guidelines when implementing m-learning and the ARCS model in the learning process established by Laurens \& Valdés (2020). The evaluation of the variables was carried out through the Instructional Materials Motivation Survey (IMMS). Both "ad hoc" tools were developed by Keller (1987b, c). 


\section{Materials and methods}

\subsection{Mobile augmented reality adapted to the ARCS model}

The ARCS model is considered as an analysis guide as well as for implementing strategies that are linked to motivation in class planification. That is why the educational proposal implemented in this study follows the steps suggested by Keller (2010), which are summarized in Fig. 1, where one can see that the first steps relate to the students' detailed knowledge, to determine his skills and attitudes toward the course. This ensures an appropriate planification for the course.

In order to do this, we implemented random interviews of the course members. In this way, we could know the students' characteristics, which is highly relevant to establish objectives that are particular to the course and to improve the conditions for motivation. The following steps are part of a systematic m-learning modality that integrate strategies related to the categories in the ARCS model. This aims to identify them and deter-mine their viability.

In the final steps the instruction materials were incorporated for future formative assessments, this helps us prove that the materials are ideal for the implemented process through determination of learning, reactions, and perceptions of students.

\subsection{Experimental design}

To be able to quantify our research finding, we conducted a statistical analysis for a single study group exposed to mAR-based learning, with a sample of sufficient size to be considered a pilot study (Creemers et al., 2010). There was no control group. No pre-experimental test or pre-test was carried out. For the validation of the pedagogical model, the expert judgment and Delphi technique were used, which consisted of

Fig. 1 Design research approach. Based on (Keller, 2000)

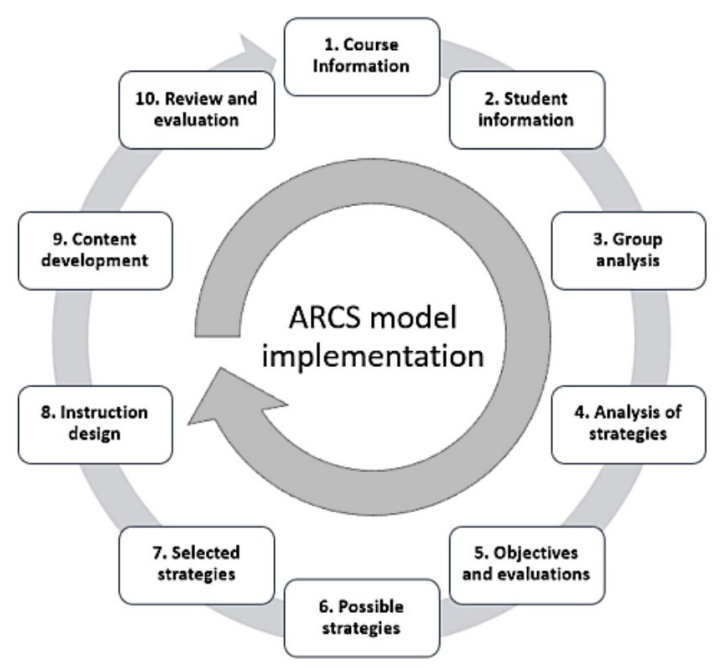


inviting a group of five expert academics, in order to collect their impressions if the methodology and solution proposed in this research is adequate to achieve the results expected learning.

The experimental design consisted of three stages, which are described below:

- Stage 1 (Pre-experimental): This phase started 16 weeks before the experimental phase. The knowledge related to the use of 3D modeling, integration and visualization AR software's were learned through the implementation of the ARCS model. Data collection instruments were designed in this phase. The guidelines of the AR project are detailed.

- Stage 2 (Experimental): In this phase, the students developed their AR project according to the Waterfall Model development method. This model is a systematic approach and sequence starting from the requirements of the project and then headed to the stage of analysis/design, implementation and testing. It is called waterfall because it consists of stage by stage sequence through which must wait for the completion of the previous stage in order to start the next stage. The Fig. 2 show the stages in the waterfall model followed.

- Stage 3 (Post-Experimental): This phase includes the evaluation of the learning achieved, and the quantification of the students' perception of the implemented methodology (ARCS model). The analysis of the data obtained is carried out.

\subsection{Case Study}

The educational strategy based on implementing AR in this study was conducted in the first semester of 2020, between the months of March-August, for 16 continuous weeks under strict sanitary restrictions (quarantine, cordon sanitaire, and ban on free movement). This strategy is substantiated by Laurens-Arredondo's (2019) proposal, which focuses on the spatial reasoning learning of university students, in the curriculum of Industrial Design and Technical Drawing of the School of Industrial Engineering of FCI, at UCM, Chile. The learning results required for students to accomplish the application of ISO and NCh norms for the visualization of geometric objects using new technologies for the elaboration of industrial design productions.

Fig. 2 Waterfall Model Process

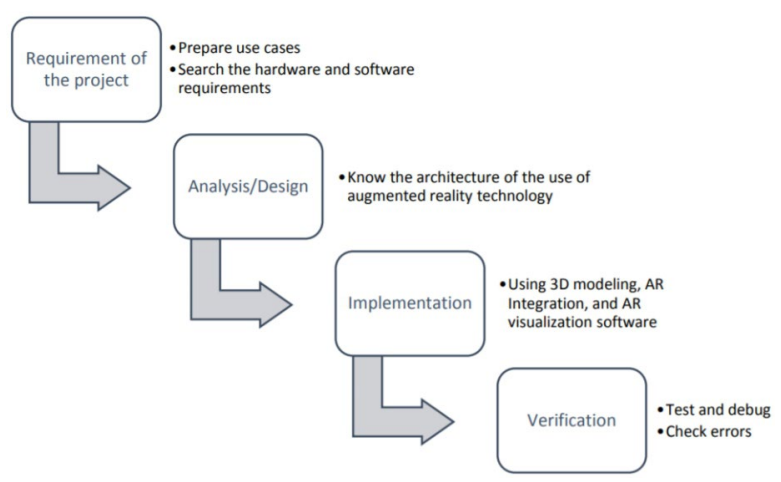


To achieve this objective the students developed and end-of-year project where, with the help of AR, not only recognize the multiview orthographic projection but also the different graphic projections; not as an abstract science but as the representations of objects in the environment (Fernández Sánchez \& Gacto Sánchez, 2014) and their connection with industrial design. The project consisted of modeling a set of industrial elements in $3 \mathrm{D}$, to later translate it into an engineering plan that should contain a frontal, lateral and isometric view of these, replicating the physical plans provided by the teacher (assembly plan of a metallic structure), these drawings also served as a

Fig. 3 Example of end-of-course project carried out by students
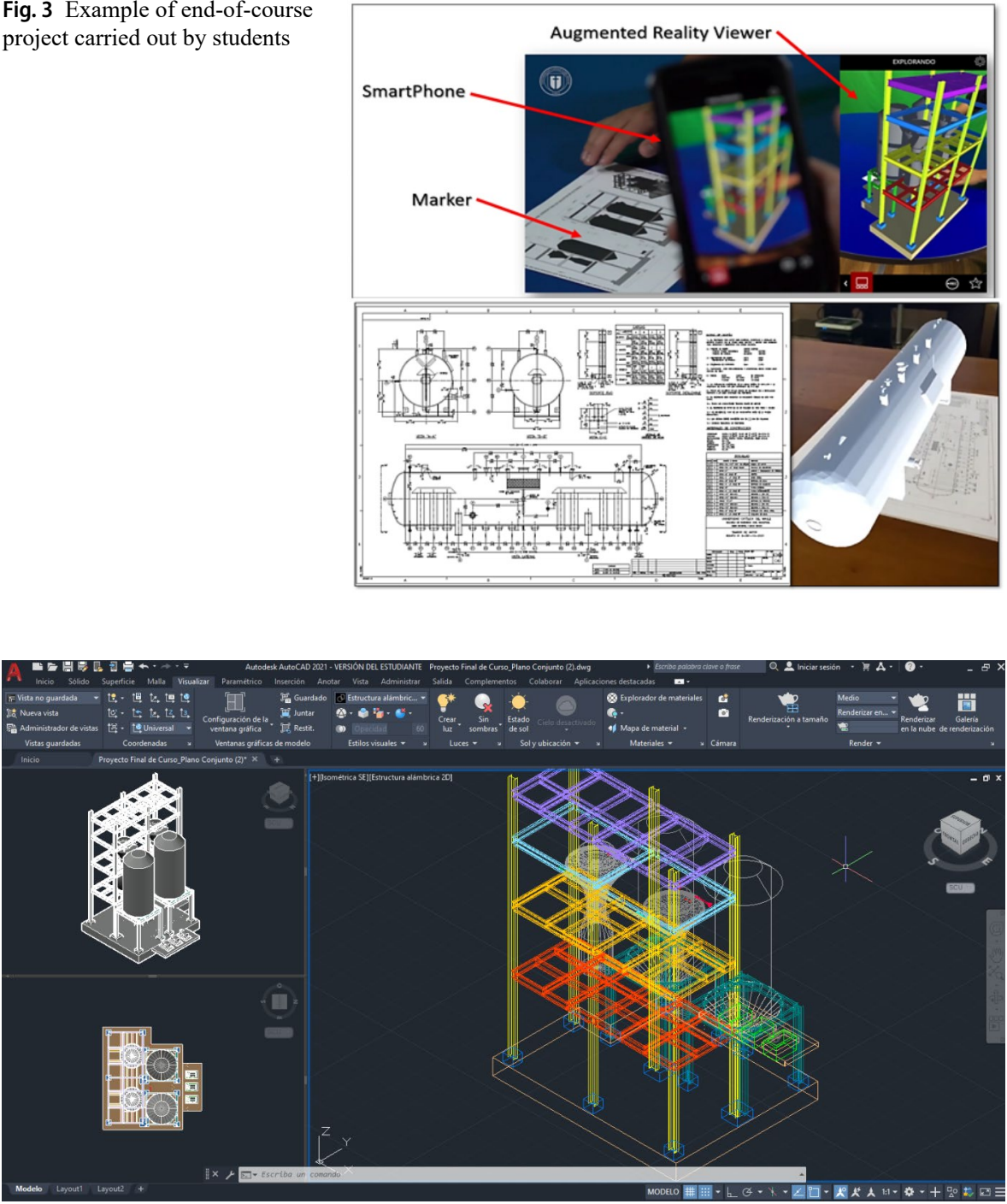

Fig. 4 Use of 3D modeling software by students 
marker in the RA project design. An example of the plane drawn by the students who served as a marker for integration with the 3D model in RA, can be seen in Fig. 3.

The RA based design introduce predetermined structures in virtual layouts, which would show up as a 3D overlay over the real physical world. The selected AR software are capable to integrate and visualize 3D models typical of the industrial discipline as e.g., metallic structures, pressure vessels, mechanical elements or similar devices, from the manufacturing drawings. For the design of the 3D models, the Autodesk signature software called AutoCAD ${ }^{\circledR}$ was used, can be seen in Fig. 4.

For the integration of the marker to the $3 \mathrm{D}$ model, the software called Creator ${ }^{\circledR}$ was used. This program accesses a cloud to upload the projects and to later be able to view them, so it was not necessary to design/create different apps to be able to view different AR projects, it just had to proceed to download the project, only with his name. For the visualization the mobile application (App) called Scope ${ }^{\circledR}$ was used, both programs are from the Aumentaty ${ }^{\circledR}$ firm. All the software used were in its free and/or academic versions.

To start using the App, the students had to have it previously installed on their smartphones, where when opening the application and launch the camera they had to view the markers, where the software automatically downloads the augmented reality project associated with said marker.

The AR design requires an augmented reality platform that combines integration software with visualization software. For this reason, Aumentaty ${ }^{\circledR}$ was selected as it offers the capability to see the designed geometry on an appropriate scale for the field of view of the smartphone user. Figure 5 shows the integration software used by the students to develop the design in augmented reality project.

We planned a work structure of 32 sessions that were conducted completely online through the MS Teams ${ }^{\circledR}$ platform, this is one of most popular online approaches and learning solutions used to support the abrupt change due to Covid-19. The sessions lasted 60 to $90 \mathrm{~min}$ each. These work sessions were divided into theoretical classes and practical classes.

The application of RA technologies during the pandemic period also showed some issues related to the rushed and compulsory adoption of Emergency Remote Education (ERE). From a practical view, there was a lack of ways to measure their experiences gained from the instructor's teaching and mobile system. In terms of theoretical approach, the proposed methodology was based on designs and adaptations of ICT

Fig. 5 Adding a 3D object to the Creator ${ }^{\circledR}$ software scene

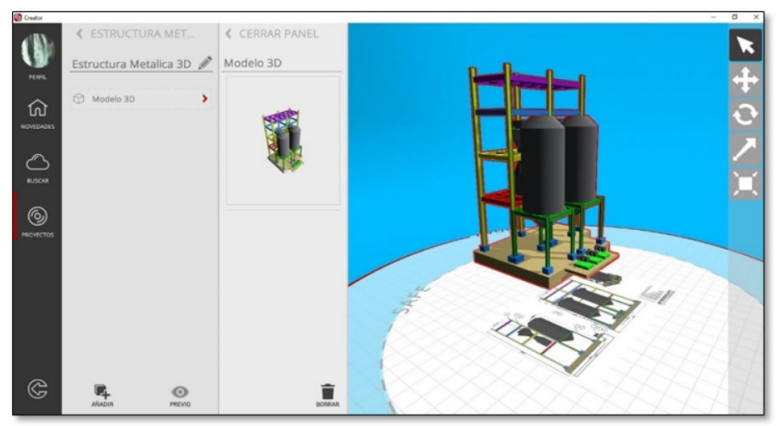


in contexts other than the health emergency due to Covid-19. Additionally, given the implementation of ERE, it was not possible to control the learning environment in the students' home, which should be an appropriate environment that facilitates learning. This might not be the case for students less favored families, who most of the times have to "attend" classes in a limited space shared with the rest of the family members.

\subsection{Data Collection Instrument}

The data collection instrument (DCI) was applied in the previously mentioned course, which was taught by the author of this study. The total number of participants was 96 students, of which $68,7 \%$ were men and $31,3 \%$ were women. This group came from diverse high school background, of which $51,2 \%$ were from subsidized high schools, $45,1 \%$ were from public schools, and 3,7\% from private schools. The students that were part of the sample were between 19 and 25 years old.

The selected DCI, also called IMMS, has been used in other research related to AR implementation in university education contexts, for courses with many and few students (Kamarainen et al., 2013; Li \& Moore, 2018). The IMMS was made up of 36 questions, Table 1 shows the codification of the asked questions; the first letter corresponding to the dimension (Attention (A), Relevance (R), Confidence (C), and Satisfaction (S)), followed by its progressive number.

The IMMS gather information from four different dimensions: Attention (12 questions) that measures how the implementation of the strategy catches and keeps students attention; Confidence (9 questions) that addresses the difficulty of the given material, as well as the use of creating and AR visualization programs; Relevance ( 9 questions) which evaluates how well information connects to knowledge, previous experiences, perceived needs, and future application potential; and Satisfaction (6 questions) which evaluates the level of enjoyment while using these programs and the perceived achievement after (Loorbach et al., 2015).

The Likert scale was used, considering 5 answers that went from $1=$ Completely Disagree, to $5=$ Completely Agree, following the recommendations made by Fabila et al., (2012). The original questions were modified and adapted, considering the courses themes and the specific application that was used. In addition, the items that were negatively worded were changed to a positive phrase, to connect the highest score to the highest degree of concurrence from the respondents.

The survey was also applied online, through the Google Forms tool, which is usually used in these types of studies (Chaiyo \& Nokham, 2017). The data was stored in an MS Excel ${ }^{\circledR}$ spreadsheet and it was processed through Rstudio software, in its 1.4.1717 version, given its proven utility and precision in the results. It is also frequently used for data analysis (Horton \& Kleinman, 2015).

\subsection{Statistical Analysis Approach}

In order to determine the distribution of the collected data set, the mean $\left(\frac{-}{x}\right)$ median $(\mathrm{Me})$ and the standard deviation $(\sigma)$ were calculated. All these statistical variables are relevant in classical inference, particularly related to the identification and study of the distribution type (Espejo, 2017). A low-value $\sigma$ indicates that most of the sam- 
Table 1 Adapted IMMS questions

\begin{tabular}{lll}
\hline Item & Questions & Code \\
\hline 2 & $\begin{array}{l}\text { There was something interesting using the programs Creator and Scope at first that drew } \\
\text { my attention. }\end{array}$ & A01 \\
8 & $\begin{array}{l}\text { The Creator and Scope programs are appealing. } \\
\text { A02 }\end{array}$ \\
11 & $\begin{array}{l}\text { The quality of the interface with the user of the Creator and Scope programs helped to } \\
\text { keep my attention. }\end{array}$ & A03
\end{tabular}

12 The Creator and Scope programs are so specific that it was difficult for me to keep my attention on them.

15 I perceived the Creator and Scope programs' design as very appealing.

17 The way in which the information is organized in the Creator and Scope programs A06 helped me maintain my attention.

20 The Creator and Scope programs have things that stimulated my curiosity. A07

22 Using the Creator and Scope programs was stimulating. A08

24 I learned some things that were surprising or unexpected by using the Creator and Scope A09 programs.

28 The variety of information shown in classes helped me keep my interest in using the Creator and Scope programs.

29 The style of interface that the Creator and Scope programs use is entertaining.

31 The type of font the interface of the Creator and Scope programs use is nice.

1 When I first saw the Creator and Scope programs, I thought they would be easy for me to use.

3 The Creator and Scope programs were easy to use.

4 After receiving the initial instruction, I felt certain that I knew what I was supposed to learn by using the Creator and Scope programs.

7 There is information related to the Creator and Scope programs so that it's easy to understand and to remember the key points

13 While I was working on the Creator and Scope programs, I was certain that I could learn C05 the related thematic content.

19 The final project made through the Creator and Scope programs was easy to do.

25 After working with the Creator and Scope programs for some time, I was certain I could C07 pass a test which evaluated the prior contents.

34 I could understand the information given to use the Creator and Scope programs. $\quad \mathrm{C} 08$

35 How the content was organized helped me trust that I would learn how to use the Cre- C09 ator and Scope programs.

6 It is clear to me how the contents approached by Creator and Scope are related to the subject matter in the course.

9 I saw examples that showed me how Augmented Reality could be important to some people.

10 Using the Creator and Scope programs successfully was important to me. R03

16 The Creator and Scope programs' content is relevant to my interests.

18 I saw explanations or examples of how people use knowledge on the Creator and Scope R05 programs.

23 The content and writing style of the Creator and Scope programs convey the feeling that R06 knowing the content it presents is worth it.

26 The Creator and Scope programs are relevant to my needs. $\quad$ R07

30 Through the Creator and Scope programs, I could relate the taught content to things I R08 have seen. done or thought in my own life.

33 I believe that the Creator and Scope programs will be useful for me. R09

5 Completing the final project through the use of the programs Creator and Scope gave S01 me a satisfactory feeling of accomplishment. 


\section{Table 1 (continued)}

\begin{tabular}{|c|c|c|}
\hline Item & Questions & Code \\
\hline$\overline{14}$ & $\begin{array}{l}\text { I enjoyed using the Creator and Scope programs so much that I would like to know how } \\
\text { to use them for other courses. }\end{array}$ & S02 \\
\hline 21 & I really enjoyed learning with the Creator and Scope programs. & S03 \\
\hline 27 & $\begin{array}{l}\text { The feedback given during and/or after using the Creator and Scope programs helped } \\
\text { me feel rewarded for my effort. }\end{array}$ & S04 \\
\hline 32 & $\begin{array}{l}\text { It feels good to successfully complete the final project by using the Creator and Scope } \\
\text { programs. }\end{array}$ & S05 \\
\hline 36 & It was a pleasure working with the Creator and Scope programs. & S06 \\
\hline 2 & $\begin{array}{l}\text { There was something interesting using the programs Creator and Scope at first that drew } \\
\text { my attention. }\end{array}$ & A01 \\
\hline
\end{tabular}

ple's data tends to group itself close to the mean, while a high-value $\sigma$ indicates that the data spreads itself further away from the mean.

In order to determine the reliability of the instrument, Cronbach's alpha $(\alpha)$ was used, given that it is one of the most appropriate statistics for this type of tools, and with values between 0 and 1 (Taber, 2018). A large number of authors find that values with $\alpha \geq 0.7$ are acceptable values. Cronbach (1951), however, even when he suggests that a higher value of alpha is preferable, argues that the key point to it should be that the scores obtained when using an instrument should be subject to interpretation.

The Kolmogorov-Smirnov (K-S) test was used to verify the assumption of normality of the data obtained from the implemented survey, given that it is broadly used in the evaluation of learning processes (Abachi et al., 2018). K-S test poses the null hypothesis that a sample originates from a normally distributed population $(\mathrm{p}<0.05)$, if said hypothesis is rejected, it implies that the analyzed data does not come from a normally distributed population. This test allowed for the appropriate selection of statistical tools according to the type of distribution of the analyzed data.

To measure the degree of concentration (flatness or peakedness) appearing in the data from the central distribution area kurtosis was used, which has a value of three (3) for normal distribution, higher values represent a more concentrated data distribution around the mean, lower values represents a skewed distribution (Aguilar, 2019). The skewness was calculated to give value to the quantity and direction of the bias (horizontal symmetry deviation), it can reach positive and negative values. Values closer to zero (0) indicate nearly perfect symmetries. Values lower than minus one $(-1)$ are considered to be an extremely biased distribution (Groeneveld \& Meeden, 1984).

\section{Results}

The implementation of the teaching strategy proposed by this investigation resulted in a level of learning achievement shown in Fig. 6, where the performance of students in the industrial design and technical drawing courses in two consecutive semesters can be seen. In the 2019-I semester, lectures were the main teaching strategy, in a pandemic-free environment. On the other hand, in the 2020-I semester, Augmented Reality was implemented as a teaching strategy, under severe health restrictions aris- 
Fig. 6 Learning level achieved with the implementation of Augmented Reality compared to other teaching strategies

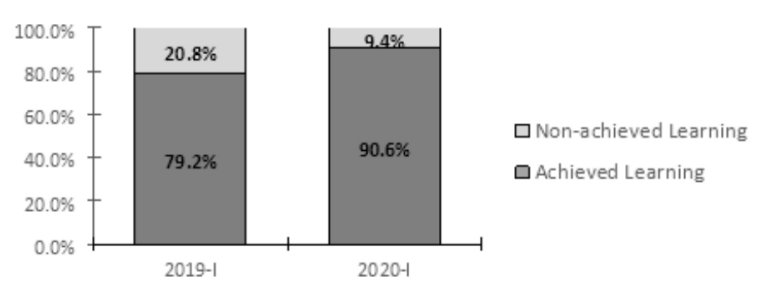

ing from the Covid-19 pandemic. In both cases the class was taught by the same professor. On Fig. 6, there is an 11,4\% increase in the achieved learning level for the analyzed semesters.

On the other hand, Table 2 shows the averages and standard deviations for each of the associated dimensions of the instrument, as well as its specific and total $\alpha$. This investigation resulted in a global $\alpha$ of 0,89 . The specific values of each of the analyzed dimensions were between 0,80 and 0,92 , which, according to different authors (Jeno et al., 2019; Zhonggen \& Xiaozhi, 2019), indicates a high degree of internal consistency, and therefore a high reliability level both globally and on each of the different dimensions that constitute it. It is observed that, in general, survey respondents show a high level of Attention and Satisfaction regarding the implementation of AR as a teaching tool, which is related to the innovative nature of this type of strategy. On the other hand, the Relevance and Confidence dimensions also show a high level of conformity, but to a lesser degree than the aforementioned dimensions, which means these aspects could use some reinforcement in the implemented methodology.

Table 3, in turn, shows the statistical results calculated according to the data obtained during the implementation of IMMS in detail. In this investigation, $\bar{x}$ ranges from 3,26 to 4,56 and $\sigma$ was between 0,75 and 1,09 points. In this table, it is possible to highlight the highest score $(4,56)$, which was obtained by the R01 question: "It is clear to me how the contents approached by Creator and Scope are related to the subject matter in the course", that is to say, the surveyed students consider that the use of AR to tackle contents related to the learning goals of the unit was meaningful. In contrast, the lowest score $(3,26)$ was obtained by question R05: "I saw examples that showed me how Augmented Reality could be important to some people", which was related to the amount of information available for the use of programs from the company Aumentaty.

Table 2 Statistics for each dimension measured by IMMS

\begin{tabular}{lllll}
\hline Variable & Dimension & & & \\
\cline { 2 - 5 } & Attention & Confidence & Relevance & $\begin{array}{l}\text { Satis- } \\
\text { faction }\end{array}$ \\
\hline Mean & 4,12 & 4,01 & 3,91 & 4,10 \\
$\begin{array}{l}\text { Standard } \\
\text { deviation }\end{array}$ & 0,91 & 0,95 & 0,97 & 1,01 \\
$\begin{array}{l}\text { Cronbach'alfa } \\
\text { particular }\end{array}$ & 0.92 & 0,80 & 0,85 & 0,89 \\
$\begin{array}{l}\text { Cronbach'alfa } \\
\text { global }\end{array}$ & 0,89 & & & \\
\hline
\end{tabular}


Table 3 Statistics for each of the questions asked in the IMMS

\begin{tabular}{|c|c|c|c|c|c|c|c|c|}
\hline \multirow[t]{2}{*}{ Item } & \multirow[t]{2}{*}{ Dimension } & \multirow[t]{2}{*}{ Mean } & \multirow[t]{2}{*}{ Standard error } & \multirow[t]{2}{*}{ Standard deviation } & \multirow[t]{2}{*}{ Kurtosis } & \multirow[t]{2}{*}{ Skewness } & \multicolumn{2}{|c|}{$\begin{array}{l}\text { Kolmogórov- } \\
\text { Smirnov }\end{array}$} \\
\hline & & & & & & & Statistics & Sig. \\
\hline 22 & $\mathrm{R} 01$ & 4.56 & 0.08 & 0.75 & 5.51 & -2.12 & 0.39 & $<0,001$ \\
\hline 12 & A12 & 4.39 & 0.08 & 0.80 & -0.36 & -0.94 & 0.35 & $<0,001$ \\
\hline 2 & A02 & 4.29 & 0.08 & 0.79 & -0.64 & -0.70 & 0.30 & $<0,001$ \\
\hline 35 & S05 & 4.28 & 0.10 & 0.99 & 1.42 & -1.39 & 0.32 & $<0,001$ \\
\hline 3 & A03 & 4.25 & 0.09 & 0.91 & 0.90 & -1.13 & 0.29 & $<0,001$ \\
\hline 4 & A04 & 4.25 & 0.09 & 0.86 & 1.27 & -1.12 & 0.27 & $<0,001$ \\
\hline 11 & A11 & 4.25 & 0.09 & 0.86 & 0.03 & -0.92 & 0.28 & $<0,001$ \\
\hline 17 & $\mathrm{C} 05$ & 4.24 & 0.09 & 0.87 & -0.45 & -0.79 & 0.29 & $<0,001$ \\
\hline 5 & A05 & 4.23 & 0.10 & 0.95 & 0.57 & -1.09 & 0.30 & $<0,001$ \\
\hline 20 & $\mathrm{C} 08$ & 4.21 & 0.09 & 0.85 & -0.36 & -0.74 & 0.27 & $<0,001$ \\
\hline 30 & R09 & 4.19 & 0.09 & 0.92 & 1.33 & -1.13 & 0.26 & $<0,001$ \\
\hline 15 & $\mathrm{C} 03$ & 4.16 & 0.09 & 0.90 & -0.62 & -0.67 & 0.27 & $<0,001$ \\
\hline 6 & A06 & 4.14 & 0.10 & 0.94 & 0.31 & -0.91 & 0.25 & $<0,001$ \\
\hline 31 & S01 & 4.14 & 0.11 & 1.07 & 1.62 & -1.37 & 0.26 & $<0,001$ \\
\hline 36 & S06 & 4.14 & 0.09 & 0.90 & -0.03 & -0.71 & 0.26 & $<0,001$ \\
\hline 21 & C09 & 4.10 & 0.09 & 0.91 & 1.12 & -0.98 & 0.23 & $<0,001$ \\
\hline 24 & R03 & 4.10 & 0.11 & 1.03 & 0.29 & -0.98 & 0.27 & $<0,001$ \\
\hline 1 & A01 & 4.07 & 0.08 & 0.82 & -0.85 & -0.37 & 0.22 & $<0,001$ \\
\hline 14 & $\mathrm{C} 02$ & 4.06 & 0.11 & 1.03 & 0.23 & -0.94 & 0.25 & $<0,001$ \\
\hline 32 & S02 & 4.05 & 0.11 & 1.08 & 0.08 & -0.98 & 0.25 & $<0,001$ \\
\hline 34 & S04 & 4.04 & 0.10 & 1.01 & 0.90 & -1.07 & 0.23 & $<0,001$ \\
\hline 13 & $\mathrm{C} 01$ & 4.03 & 0.10 & 1.00 & -1.17 & -0.45 & 0.28 & $<0,001$ \\
\hline 16 & $\mathrm{C} 04$ & 4.02 & 0.11 & 1.07 & 0.53 & -1.05 & 0.24 & $<0,001$ \\
\hline 25 & R04 & 4.01 & 0.10 & 0.97 & -0.56 & -0.52 & 0.25 & $<0,001$ \\
\hline 10 & A10 & 4.00 & 0.09 & 0.88 & 1.37 & -0.94 & 0.26 & $<0,001$ \\
\hline 19 & $\mathrm{C} 07$ & 4.00 & 0.09 & 0.89 & 0.34 & -0.72 & 0.23 & $<0,001$ \\
\hline 33 & S03 & 3.98 & 0.10 & 1.03 & 0.74 & -1.03 & 0.25 & $<0,001$ \\
\hline 27 & R06 & 3.93 & 0.09 & 0.91 & -0.22 & -0.46 & 0.19 & $<0,001$ \\
\hline 8 & A08 & 3.92 & 0.11 & 1.04 & 0.43 & -0.80 & 0.21 & $<0,001$ \\
\hline 7 & A07 & 3.88 & 0.10 & 0.99 & 0.50 & -0.75 & 0.21 & $<0,001$ \\
\hline 28 & R07 & 3.84 & 0.10 & 1.01 & -0.38 & -0.43 & 0.20 & $<0,001$ \\
\hline 29 & R08 & 3.84 & 0.08 & 0.81 & -0.78 & -0.07 & 0.22 & $<0,001$ \\
\hline 9 & A09 & 3.73 & 0.11 & 1.07 & -0.42 & -0.43 & 0.18 & $<0,001$ \\
\hline 23 & R02 & 3.48 & 0.13 & 1.26 & -0.55 & -0.53 & 0.17 & $<0,001$ \\
\hline 18 & C06 & 3.27 & 0.10 & 1.02 & -0.46 & 0.10 & 0.24 & $<0,001$ \\
\hline 26 & R05 & 3.26 & 0.11 & 1.09 & -0.26 & -0.34 & 0.20 & $<0,001$ \\
\hline
\end{tabular}

Table 3 shows the kurtosis, determined by the collected data, which ranged from $-1,17$ to $+5,51$ points, which shows that $58,3 \%$ of the variables have a leptokurtic distribution, that is to say, there is a great concentration of data in most of the variables. $38,8 \%$ have a platykurtic distribution, in other words, a low concentration of data. Finally, barely $2,9 \%$ shows a mesokurtic distribution, i.e. a normal data concentration. 
The established skewness varied between $-2,01$ and 0,10 , which shows that the tail of the distribution is elongated towards values that are smaller than the mean (left). This shows that the data is not behaving like a normal distribution would. To test this hypothesis, a Kolmogórov-Smirnov test was conducted (significance $=5 \%$ ). As a result, it was proven the data were not distributed normally, given that the p-value is smaller than the established significance for each of the analyzed variables.

On the other hand, Fig. 7 shows the distribution range of the obtained results with the implementation of the IMMS instrument on students after using AR, for each of the items.

Figure 7 shows in an orderly and grouped manner the different dimensions tackled by the IMMS instrument, the means of the obtained results for each measured variable. With the help of this type of graph, it is possible to easily compare the quantitative within a data group, visually highlighting atypical results. It also shows the atypical or extreme values compared to the mean (whiskers), given its influence in the data analysis (Flores \& Flores, 2018).

Finally, Fig. 7 shows that every surveyed person has a relatively homogenous opinion when it comes to the answers of the satisfaction and attention dimensions, locating them in a segment with a high degree of agreement, but with some exceptions such as item C06 (confidence dimension) and items R02 and R05 (relevance dimension), where values have a significant drop, locating them close to the mid-tier of the scale.

\section{Discussion}

This research is aimed at assessing mAR implemented in the context of the COVID19 pandemic. In order to answer the research questions, an experiment was devel-

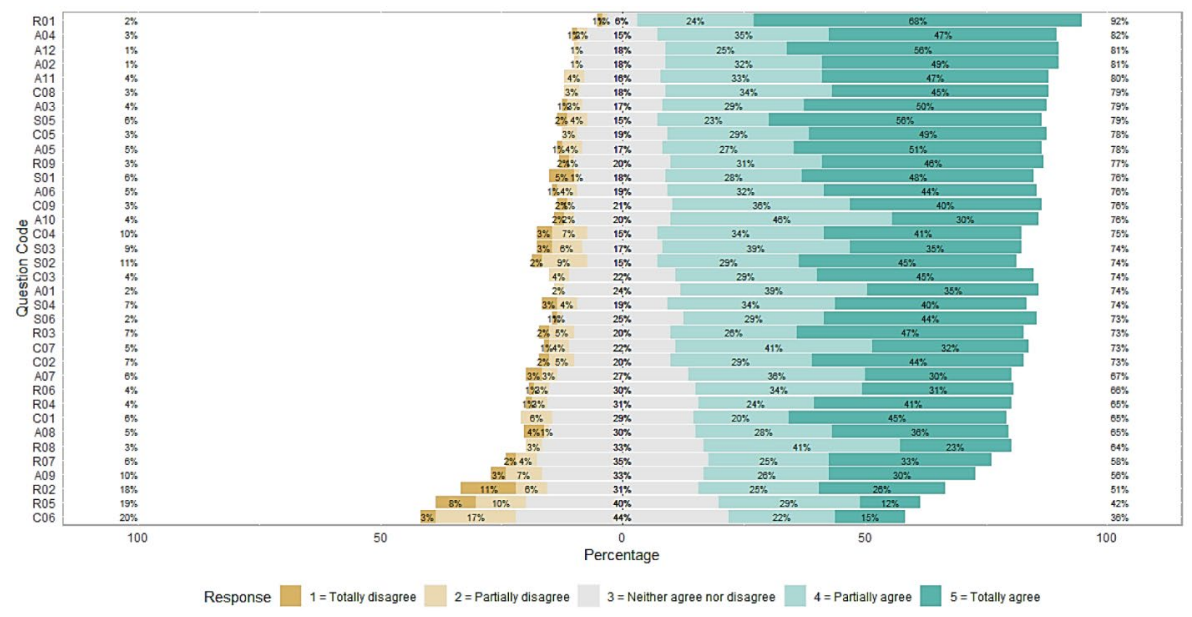

Fig. 7 University students' perceptions in the implementation of mAR as a pedagogical tool 
oped where it was possible to estimate the levels of motivation in university students after the use of AR technology.

The results of this pilot study revealed that specific type of technology (mAR) could be considered as an effective tool on Industrial Design and Technical Drawing teaching, since it was showed to be a pedagogical strategy that keeps the students engaged in learning and motivate them into participating actively in the ERE process. This research demonstrated the potential of the AR technology to help teachers improve learning process in the pandemic context, supported by ARCS model of motivation, a flexible curriculum along with technological preparedness (RQ1).

The waterfall model proved to be a valid methodology for the design of mAR projects in times of pandemic, given its ease of use and implementation. This model is frequently used when all the system requirements can be defined as a whole, explicit, and right at the beginning of the project, then the products can run well and fewer problems (RQ2).

The main issues found in this research can be classified into pedagogical issues, hardware issues and software issues. In relation to pedagogical issues: (a) Given the implementation of ERE, the control of the learning environment was not possible. In relation to hardware issues: (b) Small display size of the mobile device creates a usability issue when the user receives information. Different device screen sizes affect the quality of interactive experience of users. Finally, in relation to software issues: (c) The AR integration software has limitations in the number of active projects (10 projects) that can be developed in parallel. The visualization software accesses a cloud to download the projects and be able to view them, which makes it dependent on the internet connection speed (RQ2).

In addition, the obtained results demonstrate its validity as an educational tool, given the high motivation level caused in the study case, despite the possible negative effects to the teaching process that the several health restrictions participants were under might have caused. This can be stated thanks to the high levels of attention, confidence, relevance and satisfaction measured through IMMS. Comparing the performance regarding the result of the expected student learning, with and without $\mathrm{AR}$, it was possible to link this performance to the degree of motivation achieved in students (RQ3). Other researchers obtain similar to the results (Hauze \& Marshall, 2020; Chang et al., 2019; Kew et al., 2018; Loorbach et al., 2015), in experiences conducted without health restrictions and on face-to-face learning. With this in mind, it is possible to state that the implemented educational strategy is viable for the positive encouraging of motivation. This demonstrates that there is a direct link with the students' performance. It was demonstrated that the ARCS model can be successfully implemented in online university courses, which is consistent with (Dinçer, 2020).

The ARCS model implementation illustrates that a person's curiosity (attention), motives and values (relevance), combined with hopes for success (confidence) and the feeling of enjoyment (satisfaction) determine the objectives that have the most importance for the students, resulting in an intentional effort to achieve the established goals. Additional environmental influences, such as the enthusiasm shown by the educational facilitator, the social values that are part of the framework, quality of teaching, clear expectations and resource availability also affect the cognitive process, which affects how much of the learning results are achieved (Keller, 1987a). 
The dimension with the highest score was Relevance (R01), which shows that the surveyed people perceived that what they were learning through the programs use and the application of it was useful in achieving this learning. The dimensions with the lowest scores were Confidence (C06) and Relevance (R06). The values were very close to each other and were related to the level of certainty given by the teacher through the different proposed activities. This shows that there is a need for the adaptation of the complexity level in order to correctly implement AR, in order to increase the confidence levels on the participants' own abilities. This perception was also influenced by the characteristics of Aumentary ${ }^{\circledR}$ programs' graphic interface, which do not generate interest.

On the other hand, despite the sample size possibly being considered insufficient according to Vallejo (2012) in order to extrapolate results to wider populations, it shows some first signs that can be used to demonstrate the potential relationship between the ARCS model implementation supported by ICTs such as AR similar to Bicen \& Kocakoyun (2018) have previously reported.

Another finding of this investigation was the verification of the high reliability levels of the used IMMS, determined by Cronbach's alpha, showing similar rates to those present in Cabero et al., (2017). This statistic is usually used by investigators to evaluate the used data collection instrument in order to compile information, especially in the characterization of questionnaires intended to measure characteristics of the emotional realm, such as motivation (Huang et al., 2006). The present research had an initial value that shows a high degree of internal coherence, so the data collected by the IMMS correctly mirror, in a valid way, the perception participants had regarding their experiences with the use of the programs to learn different topics (RQ4).

The data analysis demonstrates there is a small significance level, which suggests that the collected data did not have a normal distribution. This was confirmed by the kurtosis and skewness values. This data normalcy check was especially important because it directly influenced the inferences and estimations made using the obtained results, as well as the statistics used to describe them (González-Estrada \& Cosmes, 2019).

\section{Conclusions}

The sudden appearance of the Covid-19 pandemic causes an unprecedented challenge for the entire university community. Educational institutions are forced to face the requirements of the pandemic to achieve a balance between the quality of teaching and maintaining the necessary educational processes. Therefore, this study sought to evaluate, in pandemic context, the relationship between motivation and meaningful learning for university students in pandemic context through the use of innovative pedagogical strategies such as mAR.

The outcomes from this study suggest a positive relationship between the participation in mAR experiences and the meaningful learning, given the high degree of acceptance and stimulation of motivation to learn found in the students. The ARCS 
model proved to be a useful design in the application of this type of technology in times of pandemic, as well as the waterfall model.

Despite the fact that many authors show that the use of mobile technologies provides advantages in terms of costs and benefits (Arici et al., 2019), it should be underlined that its use is dependent of good performance of the hardware and software involved and that its design the following must be included: ease of use, flexibility for its adaptation to different contexts and validated pedagogical models.

Overall, this research provides a validated measurement model, as well as solid scentific references which aim to encourage the use of mAR by teachers both during the pandemic and after it. This is because it was proven that its implementation positively encourage students' interest in learning and confidence in themselves. So, these types of educational strategies stand out not only for their innovative nature, but also because they are tools that manage to effectively incorporate mobile technology into the learning process.

Future research can provide more knowledge on how deeply students can be affected by the academic fatigue typical of ERE.

Funding This research received no external funding.

Data Availability Statement The data presented in this study are available on request from the corresponding author.

\section{Declarations}

Conflict of interest The author declare no conflict of interest.

\section{References}

Abachi, H. M., Hosseini, S., Maskouni, M. A., Kangavari, M., \& Cheung, N. M. (2018). Statistical Discretization of Continuous Attributes Using Kolmogorov-Smirnov Test. In J. Wang, G. Cong, J. Chen, \& J. Qi (Eds.), Databases Theory and Applications. ADC 2018, (10837 vol.), 309-315. Cham: Springer. Lecture Notes in Computer Science https://doi.org/10.1007/978-3-319-92013-9_25

Aguilar, L. E. B. (2019). Diferencias en la estimación del coeficiente de curtosis en diferentes softwares estadísticos. e-Agronegocios, 5(2), 1-14. https://doi.org/10.18845/rea.v5i2.4456

Alchamdani, A., Fatmasari, F., Anugrah, E. R., Sari, N. P., Putri, F., \& Astina, A. (2020). The Impact of Covid19 Pandemic on Online Learning Process in the College at Southeast Sulawesi. Jurnal Kesehatan Lingkungan, 12(1), 129-136. https://doi.org/10.20473/jkl.v12i1si.2020.129-136

Alioon, Y., \& Delialioğlu, Ö. (2019). The effect of authentic m-learning activities on student engagement and motivation. British Journal of Educational Technology, 50(2), 655-668. https://doi.org/10.1111/ bjet. 12559

Aristovnik, A., Keržič, D., Ravšelj, D., Tomaževič, N., \& Umek, L. (2020). Impacts of the COVID-19 Pandemic on Life of Higher Education Students: A Global Perspective. Sustainability, 12(20), 8438. https://doi.org/10.3390/su12208438

Arici, F., Yildirim, P., Caliklar, Ş., \& Yilmaz, R. M. (2019). Research trends in the use of augmented reality in science education: Content and bibliometric mapping analysis. Computers \& Education, 142, 103647. https://doi.org/10.1016/j.compedu.2019.103647

Aşıksoy, G., \& Özdamlı, F. (2016). Flipped Classroom adapted to the ARCS Model of Motivation and applied to a Physics Course. Eurasia Journal of Mathematics, Science and Technology Education, 12(6), 1589-1603. https://doi.org/10.12973/eurasia.2016.1251a 
Bahasoan, A. N., Ayuandiani, W., Mukhram, M., \& Rahmat, A. (2020). Effectiveness of Online Learning In Pandemic Covid-19. International Journal of Science, Technology \& Management, 1(2), 100-106. https://doi.org/10.46729/ijstm.v1i2.30

Banchoff, C. M., Fava, L. A., Schiavoni, M. A., \& Martin, E. S. (2019). Aplicaciones interactivas usando realidad aumentada y realidad virtual. XXI Workshop de Investigadores en Ciencias de la Computación (WICC 2019, Universidad Nacional de San Juan)

Bicen, H., \& Kocakoyun, S. (2018). Perceptions of students for gamification approach: Kahoot as a case study. International Journal of Emerging Technologies in Learning (iJET), 13(02), 72-93

Blizak, D., Blizak, S., Bouchenak, O., \& Yahiaoui, K. (2020). Students' Perceptions Regarding the Abrupt Transition to Online Learning During the COVID-19 Pandemic: Case of Faculty of Chemistry and Hydrocarbons at the University of Boumerdes-Algeria. Journal of Chemical Education, 97(9), 2466-2471. https://doi.org/10.1021/acs.jchemed.0c00668

Cabero, J., Fernández Robles, B., \& Marín, V. (2017). Dispositivos móviles y realidad aumentada en el aprendizaje del alumnado universitario. Revista Iberoamericana de Educación a Distancia, 20(2), 167-185. https://doi.org/10.5944/ried.20.2.17245

Cañabate, D., Aymerich, M., Falgàs, M., \& Gras, E. (2014). Teaching methods: Motivation and learning perceptions of university students. Educar, 50(2), 427. https://doi.org/10.5565/rev/educar.664

Carrillo, M., Padilla, J., Rosero, T., \& Villagómez, M. S. (2009). La motivación y el aprendizaje. Alteridad, 4(1), 20-33

Chaiyo, Y., \& Nokham, R. (2017). The effect of Kahoot, Quizizz and Google Forms on the student's perception in the classrooms response system. 2017 International Conference on Digital Arts, Media and Technology (ICDAMT), 178-182. https://doi.org/10.1109/ICDAMT.2017.7904957

Chang, Y. H., Chao, P. C., \& Fang, R. J. (2019). ARCS and RGT Integrated High-Efficiency E-Books. Education Sciences, 9(2),94. https://doi.org/10.3390/educsci9020094

Chin, K. Y., \& Wang, C. S. (2021). Effects of augmented reality technology in a mobile touring system on university students' learning performance and interest. Australasian Journal of Educational Technology, 37(1), 27-42. https://doi.org/10.14742/ajet.5841

Copertari, S., \& Lopes, C. N. (2020). Virtualización de la Educación en Tiempos de Pandemia. Revista Educ@ção Cientifica,4(7), 891-895

Creemers, B., Kyriakides, L., \& Sammons, P. (2010). Methodological Advances in Educational Effectiveness Research. Routledge. https://doi.org/10.4324/9780203851005

Cronbach, L. J. (1951). Coefficient alpha and the internal structure of tests. psychometrika, 16(3), 297-334

Cruz, N. M., Pérez, V. M., \& Cantero, C. T. (2009). Influencia de la motivación intrínseca y extrínseca sobre la transmisión de conocimiento. El caso de una organización sin fines de lucro. CIRIECEspaña, Revista de Economía Pública, Social y Cooperativa, 66, 187-211

Dinçer, S. (2020). The effects of materials based on ARCS Model on motivation: A meta-analysis. Ilkögretim Online, 19(2), 1016-1042

Elizabeth, González-Estrada Waldenia, Cosmes (2019). Shapiro-Wilk test for skew normal distributions based on data transformations. Journal of Statistical Computation and Simulation, 89(17) 3258-3272 https://doi.org/10.1080/00949655.2019.1658763

Espejo, M. R. (2017). Estimación de la desviación estándar. Estadística Española, 59(192), 37-44

Fabila, A. M., Minami, H., \& Sandoval, M. J. I. (2012). La Escala de Likert en la evaluación docente: Acercamiento a sus características y principios metodológicos.Perspectivas docentes, 50

Fardoun, H., González, C., Collazos, C., \& Yousef, M. (2020). Exploratory Study in Iberoamerica on the Teaching-Learning Process and Assessment Proposal in the Pandemic Times. Education in the Knowledge Society, 21(17), 1-9. https://doi.org/10.14201/eks

Faridi, H., Tuli, N., Mantri, A., Singh, G., \& Gargrish, S. (2020). A framework utilizing augmented reality to improve critical thinking ability and learning gain of the students in Physics. Computer Applications in Engineering Education. https://doi.org/10.1002/cae.22342. n/a(n/a)

Fauzi, I., \& Khusuma, I. H. S. (2020). Teachers' Elementary School in Online Learning of COVID-19 Pandemic Conditions. Jurnal Iqra': Kajian Ilmu Pendidikan, 5(1), 58-70. https://doi.org/10.25217/ ji.v5i1.914

Fernández Sánchez, A., \& Gacto Sánchez, M. (2014). Nuevas herramientas tecnológicas para la didáctica del dibujo técnico en bachillerato.54-63. https://repositorio.upct.es/handle/10317/3961

Flores, J., \& Flores, R. (2018). La enseñanza del diagrama de caja y bigotes para mejorar su interpretación. Revista Bases de la Ciencia, 3(1), 69-75

Gagné, R. M., de la Orden, A., \& Soler, A. G. (1987). Las condiciones del aprendizaje. 248-249 
García, I. (2020). Estrategias didácticas motivadoras para la mejora de la visión espacial [Master's Thesis, Univarsidad Católica del Murcia]. http://hdl.handle.net/10952/4388

Gómez-Carrasco, C. J., Monteagudo-Fernández, J., Moreno-Vera, J. R., \& Sainz-Gómez, M. (2019). Effects of a Gamification and Flipped-Classroom Program for Teachers in Training on Motivation and Learning Perception. Education Sciences, 9(4), 299. https://doi.org/10.3390/educsci9040299

Groeneveld, R. A., \& Meeden, G. (1984). Measuring skewness and kurtosis. Journal of the Royal Statistical Society: Series D (The Statistician), 33(4), 391-399. https://doi.org/10.2307/2987742

Hauze, S., \& Marshall, J. (2020). Validation of the Instructional Materials Motivation Survey: Measuring Student Motivation to Learn via Mixed Reality Nursing Education Simulation. International Journal on E-Learning, 19(1), 49-64

Hidayah, N. (2020). Mobile-learning feedback and students' self- efficacy in new normal post covid-19. Journal Of Educational Experts (JEE), 3(2), 39-45. https://doi.org/10.30740/jee.v3i2p39-45

Horton, N., \& Kleinman, K. (2015). Using R and RStudio for Data Management, Statistical Analysis and Graphics. Journal of Statistical Software, 68(1), 1-7. https://doi.org/10.18637/jss.v068.b04

Huang, W., Huang, W., Diefes-Dux, H., \& Imbrie, P. K. (2006). A preliminary validation of Attention, Relevance, Confidence and Satisfaction model-based Instructional Material Motivational Survey in a computer-based tutorial setting. British Journal of Educational Technology, 37(2), 243-259. https:// doi.org/10.1111/j.1467-8535.2005.00582.x

Iwanaga, J., Loukas, M., Dumont, A. S., \& Tubbs, R. S. (2020). A review of anatomy education during and after the COVID-19 pandemic: Revisiting traditional and modern methods to achieve future innovation. Clinical Anatomy, n/a(n/a). https://doi.org/10.1002/ca.23655

Jeno, L. M., Vandvik, V., Eliassen, S., \& Grytnes, J. A. (2019). Testing the novelty effect of an m-learning tool on internalization and achievement: A Self-Determination Theory approach. Computers \& Education, 128, 398-413. https://doi.org/10.1016/j.compedu.2018.10.008

Kamarainen, A. M., Metcalf, S., Grotzer, T., Browne, A., Mazzuca, D., Tutwiler, M. S., \& Dede, C. (2013). EcoMOBILE: Integrating augmented reality and probeware with environmental education field trips. Computers \& Education, 68, 545-556. https://doi.org/10.1016/j.compedu.2013.02.018

Keller, J. (2000). How to integrate learner motivation planning into lesson planning: The ARCS model approach.VII Semanario, 17

Keller, J. M. (1987a). Development and use of the ARCS model of instructional design. Journal of instructional development, 10(3), 2

Keller, J. M. (1987b). Instructional materials motivation scale (IMMS). Unpublished manuscript. The Florida State University

Keller, J. M. (1987c). Strategies for stimulating the motivation to learn. Performance and instruction, 26(8), 1-7

Keller, J. M. (2010). The Arcs Model of Motivational Design. En J. M. Keller (Ed.), Motivational Design for Learning and Performance: The ARCS Model Approach (pp. 43-74). Springer US. https://doi. org/10.1007/978-1-4419-1250-3_3

Kew, S. N., Petsangsri, S., Ratanaolarn, T., \& Tasir, Z. (2018). Examining the motivation level of students in e-learning in higher education institution in Thailand: A case study. Education and Information Technologies, 23(6), 2947-2967. https://doi.org/10.1007/s10639-018-9753-z

Laurens, L., \& Valdés, H. (2020). Evaluation of University Students Motivation in Learning Kinematics Through M-Learning. 2020 39th International Conference of the Chilean Computer Science Society (SCCC), 1-8. https://doi.org/10.1109/SCCC51225.2020.9281163

Laurens-Arredondo, L. A. (2019). Realidad Aumentada: Propuesta metodológica para la didáctica de diseño industrial en el ámbito universitario. Revista científica electrónica de educación y comunicación en la sociedad del conocimiento, 19(2), Article 2. http://eticanet.org/revista/index.php/eticanet/ article/view/186

Laurens-Arredondo, L. A. (2020). Realidad Aumentada Móvil: Una estrategia pedagógica en el ámbito universitario/Mobile Augmented Reality: A pedagogical strategy in the university environment. Universidad del Zulia, 43(3), 142-149. https://doi.org/10.22209/rt.v43n3a04. Revista Técnica de la Facultad de Ingeniería

Lecon, C. (2020). Corona E-Learning Cocktail: Sustainability of University Education in Times of Pandemics. 2020 15th International Conference on Computer Science Education (ICCSE), 57-65. https://doi.org/10.1109/ICCSE49874.2020.9201619

Li, K., \& Keller, J. M. (2018). Use of the ARCS model in education: A literature review. Computers \& Education, 122, 54-62. https://doi.org/10.1016/j.compedu.2018.03.019 
Li, K., \& Moore, D. R. (2018). Motivating students in massive open online courses (MOOCs) using the attention, relevance, confidence, satisfaction (arcs) model. Journal of Formative Design in Learning, 2(2), 102-113. https://doi.org/10.1007/s41686-018-0021-9

Loorbach, N., Peters, O., Karreman, J., \& Steehouder, M. (2015). Validation of the Instructional Materials Motivation Survey (IMMS) in a self-directed instructional setting aimed at working with technology. British Journal of Educational Technology, 46(1), 204-218. https://doi.org/10.1111/bjet.12138

Mad, S., Omar, N. A., Sarudin, E. S., \& Aziz, N. H. (2020). Perception and intention to use e-learning from students' point of view- an evidence from Malaysia local university/Salina Mad ... Et al.]. Journal of Computing Research and Innovation (JCRINN), 5(2), 11-20

Martínez, N. M. M., \& Cevallos, M. B. M. (2021). COVID-19 desde una óptica tecno-educativa a través de markerspaces. IJERI: International Journal of Educational Research and Innovation, 15, 57-72. https://doi.org/10.46661/ijeri.4898

Mojibur, M. (2020). Online Learning in Higher Education During Covid-19 Pandemic: Students' Perceptions. Journal of Talent Development and Excellence, 12(2), 3644-3651

Monasterio, D., \& Briceño, M. (2020). Educación mediada por las tecnologías: Un desafío ante la coyuntura del Covid-19. Educación mediada por las tecnologías: Un desafío ante la coyuntura del Covid19, 137-148

Müssig, J., Clark, A., Hoermann, S., Loporcaro, G., Loporcaro, C., \& Huber, T. (2020). Imparting Materials Science Knowledge in the Field of the Crystal Structure of Metals in Times of Online Teaching: A Novel Online Laboratory Teaching Concept with an Augmented Reality Application. Journal of Chemical Education, 97(9), 2643-2650. https://doi.org/10.1021/acs.jchemed.0c00763

Noguera, E. G. D., Altuve, G. N., \& Gottberg, M. A. N. (2012). El aprendizaje visto desde la perspectiva ecléctica de Robert Gagné y el uso de las nuevas tecnologías en educación superior. Universidades, $62(53), 50-56$

Nugroho, R. A., Basari, A., Suryaningtyas, V. W., \& Cahyono, S. P. (2020). University Students' Perception of Online Learning in Covid-19 Pandemic: A Case Study in a Translation Course. 2020 International Seminar on Application for Technology of Information and Communication (iSemantic), 225-231. https://doi.org/10.1109/iSemantic50169.2020.9234251

Nur, A. S., Widyastuti, M., \& Quinones, C. A. (2020). Students' Perception of Online Learning during COVID-19 Pandemic: A Case Study on the English Students of STKIP Pamane Talino | Soshum: Jurnal Sosial dan Humaniora. Soshum: Jurnal Sosial Dan Humaniora, 10(2), 225-235. https://doi. org/10.31940/soshum.v10i2.1316

Oliva, J. D., Gómez, J. C., de la Cruz Gámez, E., \& Reyna, R. H. (2019). Aplicaciones Móviles Basadas en Realidad Aumentada como Herramientas de Apoyo al Proceso Enseñanza-Aprendizaje. Memorias del Congreso Internacional de Investigación Academia Journals Morelia 2019, 11,2048-2053. http:// www.itacapulco.net/depi/wp-content/uploads/2020/01/Juan-Daniel-Oliva-Vazquez.pdf

Ratten, V. (2020). Coronavirus (Covid-19) and the entrepreneurship education community. Journal of Enterprising Communities: People and Places in the Global Economy, ahead-of-print(ahead-ofprint). https://doi.org/10.1108/JEC-06-2020-0121

Ríos, C. (2020). COVID-19 y Educación Superior Universitaria Pública del Perú. Revista Clake Education, 1(02), 1-1

Sepasgozar, S. M. E. (2020). Digital Twin and Web-Based Virtual Gaming Technologies for Online Education: A Case of Construction Management and Engineering. Applied Sciences, 10(13), 4678. https:// doi.org/10.3390/app10134678

Taber, K. S. (2018). The use of Cronbach's alpha when developing and reporting research instruments in science education. Research in Science Education, 48(6), 1273-1296. https://doi.org/10.1007/ s11165-016-9602-2

Vallejo, P. M. (2012). Tamaño necesario de la muestra:?` Cuántos sujetos necesitamos. Estadística aplicada, 24(1), 22-39

Zhonggen, Y., \& Xiaozhi, Y. (2019). An extended technology acceptance model of a mobile learning technology. Computer Applications in Engineering Education, 27(3), 721-732. https://doi.org/10.1002/ cae. 22111

Publisher's Note Springer Nature remains neutral with regard to jurisdictional claims in published maps and institutional affiliations. 